\title{
Evidence for a Local Effect of Leptin in Bovine Mammary Gland ${ }^{1}$
}

\author{
L. F. P. Silva, ${ }^{\star 2}$ M. J. VandeHaar, ${ }^{*}$ M. S. Weber Nielsen, ${ }^{*}$ and G. W. Smith ${ }^{\star}, \dagger$ \\ ${ }^{*}$ Department of Animal Science and \\ †Department of Physiology, \\ Michigan State University, \\ East Lansing 48824
}

\begin{abstract}
On average, high-energy diets promoting body growth rates above $1 \mathrm{~kg} / \mathrm{d}$ before puberty impair mammary development by 15 to $20 \%$ in cattle. We hypothesized that leptin, a protein produced by adipocytes, mediates the inhibitory effect of high-energy diets on mammary development. Therefore, our objectives were to determine the effect of leptin on mammary epithelial cell proliferation, and the distribution of mRNA for two leptin receptor isoforms in prepubertal bovine mammary glands and other peripheral tissues. Addition of leptin to culture media containing either $5 \mathrm{ng} / \mathrm{ml}$ of insulin-like growth factor-I (IGF-I) or $1 \%$ fetal bovine serum decreased DNA synthesis of a bovine mammary epithelial cell line (MAC-T) in a dosedependent manner. The minimal doses of leptin that decreased IGF-I- and fetal bovine serum-stimulated cell proliferation were 64 and $1 \mathrm{ng} / \mathrm{ml}$, respectively. In addition, we determined that MAC-T cells and isolated bovine mammary epithelial cells express the long form of leptin receptor $(\mathrm{Ob}-\mathrm{Rb}) \mathrm{mRNA}$. Ob-Rb mRNA was detected in all bovine tissues examined. In contrast with reports on other species, mRNA expression of the short form of leptin receptor (Ob-Ra) was detected only in bovine liver, pituitary body, and spleen. These results support the concept that leptin mediates the inhibitory effect of high-energy diets on mammary development.
\end{abstract}

(Key words: bovine mammary epithelial cell line, leptin receptor, proliferation)

Abbreviation key: bp = base pairs, DMEM = Dulbecco's modified Eagle's media, FBS = fetal bovine serum, IL-6 = interleukin-6, oLeptin = recombinant ovine leptin, MAC-T = bovine mammary epithelial cell line,

\footnotetext{
Received March 8, 2002.

Accepted July 7, 2002.

Corresponding author: M. J. VandeHaar; e-mail: mikevh@pilot. msu.edu.

${ }^{1}$ This research was partially supported by USDA National Research Initiative Competitive Grants program (\#00-35206-9386) and the Michigan Agriculture Experiment Station.

${ }^{2}$ CAPES' scholar-Brazil.
}

$\mathbf{O b}-\mathbf{R}=$ leptin receptor, $\mathbf{O b}-\mathbf{R a}=$ short isoform of leptin receptor, $\mathbf{O b}-\mathbf{R b}=$ long isoform of leptin receptor, PMEC = primary mammary epithelial cells, $\mathbf{R T}=$ reverse transcription, RP-L19 = bovine ribosomal protein L-19, STAT = signal transducers and activators of transcription.

\section{INTRODUCTION}

Heifers fed high-energy diets that promote body growth rates greater than $1 \mathrm{~kg} / \mathrm{d}$ before puberty have impaired mammary gland development (Sejrsen et al., 1982). These rapid-growth regimens enable earlier calving and reduce heifer-rearing costs, but also lead to an increased volume of adipocytes in mammary parenchyma (Capuco et al., 1995) and reduced subsequent milk production (Radcliff et al., 2000). This phenomenon has been known for more than $85 \mathrm{yr}$, but the mechanisms responsible are unknown (Eckles, 1915). High-energy intake increases IGF-I concentrations in the serum of prepubertal heifers, but it also increases fat deposition (Radcliff et al., 1997). Increased body fat, in turn, increases serum leptin concentrations (Delavaud et al., 2000). We hypothesized that leptin, a protein produced by adipocytes, mediates the inhibitory effect of energy intake on mammary development.

Since its discovery in 1994 (Zhang et al., 1994), leptin has been implicated in several metabolic pathways regulating basic body functions, such as energy intake and cell division (Houseknecht et al., 1998). Most of our current knowledge of the physiological role of leptin comes from human and rodent studies. For example, activation of the leptin receptor in the central nervous system is required for maintenance of normal BW in rodents (Friedman and Halaas, 1998). Mice deficient in leptin $(o b / o b)$ or deficient in leptin receptor expression $(d b / d b)$ weigh three times more than normal mice (Friedman and Halaas, 1998). Administration of leptin can also reduce BW in wild-type mice (Friedman and Halaas, 1998). Evidence exists for a similar role for leptin in livestock species (Barb et al., 1998). Although leptin reduces feed intake through the central nervous system (Friedman and Halaas, 1998), it may also act in peripheral tissues, such as 
the ovary and pancreas ( Chen et al., 1997; Agarwal et al., 1999). The pathways for the effects of leptin in peripheral tissues are not known. If leptin has a direct effect on peripheral tissues, such as the mammary gland, then the leptin receptor must be expressed in these tissues.

The leptin receptor (Ob-R), first identified by expression cloning in 1995, is a member of the class I cytokine receptor family, and is present in five alternatively spliced forms: Ob-Ra, Ob-Rb, Ob-Rc, Ob-Rd, and Ob-Re (Tartaglia et al., 1995). The long isoform of the receptor $(\mathbf{O b}-\mathbf{R b})$, is predominantly expressed in the hypothalamus, and is essential for the weight-reducing effect of leptin. The other isoforms lack some or all of Ob-Rb intracellular domains (Friedman and $\mathrm{Ha}-$ laas, 1998). The short form of the leptin receptor (Ob$\mathbf{R a}$ ), is expressed in many different tissues in mice, and is capable of leptin-mediated signaling (Bjorbaek et al., 1997). However, the physiological significance of Ob-Ra signaling is not known. In cattle, the tissue distribution of leptin receptor isoforms is not well known. Previously, in cattle, expression of Ob-R has been reported only for the adrenal gland (Yanagihara et al., 2000).

Our objectives were to determine the effects of leptin on mammary epithelial cell proliferation and distribution of $\mathrm{Ob}-\mathrm{Ra}$ and $\mathrm{Ob}-\mathrm{Rb}$ mRNA in prepubertal bovine mammary gland and peripheral tissues.

\section{MATERIALS AND METHODS}

\section{Cell Culture}

The MAC-T cell line, an immortalized bovine mammary epithelial cell (Huynh et al. 1991; Nexia Biotechnologies, Ste-Anne-de-Bellevue, Quebec, Canada), was cultured based on the methods described by Woodward et al. (1994). Briefly, MAC-T cells were plated at a density of $5 \times 10^{3}$ cells/well in 24 -well plates (Corning, NY) coated with $250 \mu \mathrm{l} / \mathrm{well}$ of a $50-\mu \mathrm{g} / \mathrm{ml}$ rat-tail collagen-I solution (Fisher Scientific, Pittsburgh, PA). The initial medium was composed of Dulbecco's Modified Eagle Media/F12 (DMEM/F12, Invitrogen, Carlsbad, CA) supplemented with $100 \mathrm{U} / \mathrm{ml}$ of penicillin, $0.1 \mathrm{mg} / \mathrm{ml}$ of streptomycin, $0.25 \mu \mathrm{g} / \mathrm{ml}$ of amphotericin B (Invitrogen), and $10 \%$ fetal bovine serum (FBS; Sigma, St. Louis, MO) for $24 \mathrm{~h}$. Cells were then washed with Dulbecco's PBS (Invitrogen) and cultured in a serum-free medium for $48 \mathrm{~h}$. The serum-free media consisted of DMEM/F12 containing BSA ( $5 \mu \mathrm{g} / \mathrm{ml})$, insulin $(1 \mathrm{ng} / \mathrm{ml})$, glutathione $(1 \mu \mathrm{g} / \mathrm{ml})$, soybean trypsin inhibitor $(1 \mu \mathrm{g} / \mathrm{ml})$, sodium selenite $(1 \mathrm{ng} / \mathrm{ml})$, and apotransferrin $(5 \mu \mathrm{g} / \mathrm{ml})$. Each 24 -well plate was divided into blocks of 12 wells, with the six treatments randomized (two wells per treatment per block). After 48 $\mathrm{h}$ on serum-free medium, the cells were grown in new serum-free media containing the hormones of interest for $3 \mathrm{~d}$, with one change of media after $2 \mathrm{~d}$. A dose response curve to IGF-I ( 0 to $100 \mathrm{ng} / \mathrm{ml}$ ) and FBS (0 to $10 \%$ ) was initially established. The treatments consisted of increasing doses ( 0 to $160 \mathrm{ng} / \mathrm{ml}$ ) of recombinant ovine leptin (oLeptin) together with $5 \mathrm{ng} / \mathrm{ml}$ IGF-I or increasing doses of oLeptin (0 to $1,000 \mathrm{ng} /$ ml) together with $1 \%$ FBS. To ensure proliferation was not reduced by contact inhibition, cell density at plating was determined to allow a maximum of $80 \%$ confluency at the end of the experiment.

Recombinant human IGF-I was obtained from GroPep Pty Ltd (Adelaide, South Australia, bovine insulin was purchased from Invitrogen, and oLeptin was from Dr. Gertler of Hebrew University, Jerusalem).

\section{Quantification of Cell Proliferation}

Incorporation of $\left[{ }^{3} \mathrm{H}\right]$-thymidine was measured using the method described by Woodward et al. (1994). Briefly, cells were cultured in treatment media for 72 $\mathrm{h}$ with $0.5 \mu \mathrm{Ci} / \mathrm{ml}$ [methyl ${ }^{3} \mathrm{H}$ ]-thymidine (ICN, Irvin, CA) added for the last $24 \mathrm{~h}$. To remove excess $\left[{ }^{3} \mathrm{H}\right]$ thymidine, cells were washed with two changes of Hank's balanced salt solution, $90 \%$ ethanol, $10 \%$ trichloroacetic acid, and $90 \%$ ethanol. Cells then were lysed with $250 \mu \mathrm{l}$ of a buffer containing $0.5 \mathrm{M} \mathrm{NaOH}$ and $0.1 \%$ Triton $\mathrm{X}-100$, and radioactivity was measured using a liquid scintillation counter.

\section{Detection of Leptin Receptor Expression}

Tissue collection and RNA isolation. Tissue samples were obtained from two prepubertal Holstein heifers (190 $\pm 14 \mathrm{~kg} \mathrm{BW})$. The prepubertal condition of the heifers was confirmed visually at slaughter by absence of a corpus luteum. The hypothalamus and pituitary body were quickly removed after opening the cranial vault. Other tissues collected were the liver, spleen, skeletal muscle, ovary, lung, tail fat, heart, and the mammary gland. In addition, mammary parenchymal tissue, mammary extraparenchymal adipose tissue, liver, skeletal muscle, and subcutaneous adipose tissue were obtained from three pubertal Holstein heifers ( $343 \pm 16 \mathrm{~kg} \mathrm{BW})$. The testis was obtained from a bull of unknown age and BW. Tissues were quickly frozen in liquid nitrogen and stored at $-80^{\circ} \mathrm{C}$ until RNA extraction.

The mammary gland was removed and brought to the laboratory for isolation of epithelial cells as previously described (Weber et al., 1999). Within $15 \mathrm{~min}$ of slaughter, samples of parenchyma and extraparenchymal adipose tissue were collected. Tissue samples 
were rapidly frozen in liquid nitrogen and stored at $-80^{\circ} \mathrm{C}$ until isolation of RNA. Primary mammary epithelial cells (PMEC) were frozen and stored in liquid nitrogen until use.

After thawing, PMEC and MAC-T cells were washed three times with basal medium and cultured in 35mm plastic dishes (Corning, NY). Cells were cultured with DMEM supplemented with $100 \mathrm{U} / \mathrm{ml}$ of penicillin, $0.1 \mathrm{mg} / \mathrm{ml}$ of streptomycin, $0.25 \mu \mathrm{g} / \mathrm{ml}$ of amphotericin $\mathrm{B}$, and $10 \%$ of FBS for $3 \mathrm{~d}$ until RNA isolation. Cultured cells were washed once with Dulbecco's PBS before RNA extraction.

Total RNA from tissue samples and cultured cells was extracted according to manufacturer's instructions using the Trizol reagent (Invitrogen). After extraction, total RNA was quantified by spectrophotometry, and integrity of $18 \mathrm{~S}$ and $28 \mathrm{~S}$ ribosomal RNA was verified by electrophoresis in a $1 \%$ agarose gel stained with ethidium bromide.

Reverse transcription (RT) PCR. Five $\mu \mathrm{g}$ of total RNA from each tissue sample was treated with RNasefree DNase I (Invitrogen), following manufacturer's instructions, to remove possible genomic DNA contamination. After denaturing at $70^{\circ} \mathrm{C}$ for $10 \mathrm{~min}$, half of the sample $(2.5 \mu \mathrm{g})$ was reverse-transcribed into cDNA with $0.5 \mu \mathrm{g}$ oligo thymidine and $200 \mathrm{U}$ Superscript II reverse transcriptase (Invitrogen) to a final volume of $20 \mu$ l, for $60 \mathrm{~min}$ at $42^{\circ} \mathrm{C}$. The other half was incubated without reverse transcriptase and used as a negative control in PCR reactions to confirm the absence of residual genomic DNA contamination after DNase treatment.

Oligonucleotide primer pairs specific for the long $(\mathrm{Ob}-\mathrm{Rb})$ or for the short form (Ob-Ra) of the leptin receptor were designed based on the known human Ob-Rb (GenBank accession number U43168) and ObRa (GenBank accession number U50748) sequence. The primers used were: 5'-ATCAGTGTCGATACATCATGGAAA-3' (position 2957) and 5'-TGAGAATGGAAGGTGTGGTGAAAT-3' (position 3355) for Ob-Rb and $5^{\prime}$-GAGAAGTACCAGTTCAGTC-3' (position 2413) and 5'-CAAAGAATGTCCGTTCTCTTC-3' (position 2690) for Ob-Ra. Primers were synthesized at the Macromolecular Structure, Sequencing, and Synthesis Facility at Michigan State University.

We chose to study Ob-Rb expression because this particular leptin receptor isoform has a complete intracellular domain with established signaling capacity and is essential for the weight-reduction effect of leptin (Friedman and Halaas, 1998). Ob-Ra is the predominant leptin receptor isoform in most peripheral tissues in rodents (Ghilardi et al., 1996) and is capable of limited leptin-mediated signaling (Bjorbaek et al.,
1997); therefore we also chose to study distribution of this particular leptin receptor in cattle.

Two $\mu \mathrm{l}$ of each $\mathrm{RT}$ reaction was used as template for PCR reactions in a final volume of $20 \mu \mathrm{l}$ with 3.0 $\mathrm{m} M \mathrm{MgCl}_{2}, 0.4 \mathrm{~m} M$ of each deoxynucleotide triphosphate (Invitrogen), $0.25 \mu M$ of each primer, $4 \mathrm{U}$ Taq polymerase (Invitrogen), and 1× PCR buffer (Invitrogen). The following amplification conditions were utilized: $95^{\circ} \mathrm{C}$ for $5 \mathrm{~min}$ followed by 40 cycles at $95^{\circ} \mathrm{C}$ for $1 \mathrm{~min}, 60^{\circ} \mathrm{C}$ for $1 \mathrm{~min}$, and $72^{\circ} \mathrm{C}$ for $1 \mathrm{~min}$. After the last cycle, reactions were held at $72^{\circ} \mathrm{C}$ for $10 \mathrm{~min}$. Primers specific for ribosomal protein L19 (RP-L19, sense 5'-GAAATCGCCAATGCCAAC-3' and antisense 5'-GGNCCTTGTCTGCCTTCA-3') were used as positive controls for all samples to verify that the RT reactions were successful. In addition to incubating the RNA without reverse transcriptase, negative control reactions were performed similarly without addition of a template from the RT reaction. Amplified cDNA were visualized by agarose gel electrophoresis and staining with ethidium bromide.

The PCR product obtained from MAC-T cell cDNA using primers specific for Ob-Rb was cloned into the pBluescript vector and subjected to fluorescent dye terminator sequencing. The bovine 402-base pair (bp) $\mathrm{Ob}-\mathrm{Rb} \mathrm{cDNA}$ was sequenced in both directions at the Michigan State University DNA Sequencing Facility, and the identity of the cDNA was confirmed based on a comparison with the sequence deposited in GenBank (U62385). To verify that the 402-bp cDNA amplified from all tissues was encoding for bovine Ob-Rb, MseIrestriction endonuclease digestions were performed with the endonucelease MseI (New England Biolabs, Beverly, MA). MseI cuts at position 209 of the 402-bp Ob-Rb cDNA, generating two fragments of 193- and 209-bp. The presence of these two fragments after MseI digestion was used as confirmation that the original 402-bp fragment coded for Ob-Rb.

The PCR product amplified from liver cDNA using primers specific for Ob-Ra was cloned and sequenced as described above for Ob-Rb. Based on the 275-bp nucleotide sequence obtained, the identity of the PCR product amplified from all tissues was verified by digestion with the endonuclease BseRI (New England Biolabs). This restriction enzyme cuts the 275-bp nucleotide fragment at position 129 , generating two fragments of 129 and $146 \mathrm{bp}$. The presence of these two fragments after BseRI digestion was used as confirmation that the original 275-bp fragment coded for Ob-Ra.

\section{Statistical Analysis}

Data from $\left[{ }^{3} \mathrm{H}\right]$-thymidine incorporation was obtained as disintegrations/min and analyzed using the following model: 


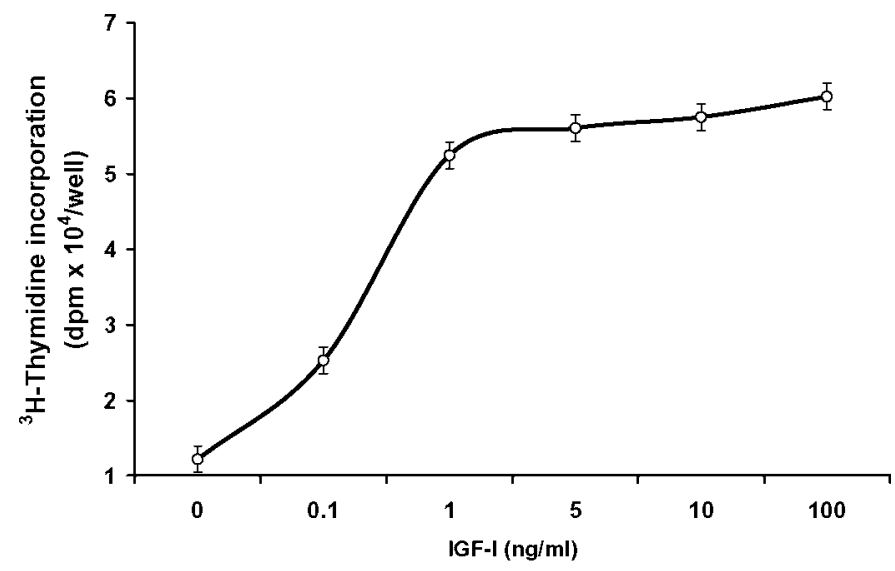

Figure 1. Effect of IGF-I on $\left[{ }^{3} \mathrm{H}\right]$-thymidine incorporation into bovine mammary epithelial cell-line cells. Cells were cultured in treatment medium for $3 \mathrm{~d}$. A pulse of $\left[{ }^{3} \mathrm{H}\right]$-thymidine was given for the last $24 \mathrm{~h}$. Values are expressed as disintegrations/min (dpm) and are presented as least squares means \pm SEM of two independent experiments $(n=4$ blocks).

$$
\begin{gathered}
\mathrm{Y}=\text { plate }+ \text { block }(\text { plate })+\text { treatment }(\text { plate } \times \text { block }) \\
+ \text { treatment }+ \text { residual }
\end{gathered}
$$

where treatment is hormone concentration.

Treatment(plate $\times$ block) was used as the error term to test for treatment effect. Differences were determined using Dunnett's test with dose 0 (no leptin) as control. Analysis was done using the MIXED procedure of SAS (2000). Values are presented as a percentage of basal $\left[{ }^{3} \mathrm{H}\right]$-thymidine incorporation where indicated.

\section{RESULTS}

\section{Leptin Inhibition of MAC-T Cell Proliferation}

As expected, DNA synthesis of MAC-T cells increased linearly with increasing concentrations of IGF-I in the media. With $5 \mathrm{ng} / \mathrm{ml}$ of IGF-I, the rate of $\left[{ }^{3} \mathrm{H}\right]$-thymidine incorporation was $90 \%$ that of the maximum observed with $100 \mathrm{ng} / \mathrm{ml}$ of IGF-I (Figure 1). Five $\mathrm{ng} / \mathrm{ml}$ of IGF-I was then used to test the effect of leptin on IGF-I-stimulated cell proliferation.

Addition of recombinant oLeptin to media containing $5 \mathrm{ng} / \mathrm{ml}$ of IGF-I decreased DNA synthesis linearly within the range of doses tested. The minimal dose of oLeptin that decreased $(P<0.05)$ DNA synthesis was $64 \mathrm{ng} / \mathrm{ml}$ (20\% decrease; Figure 2). With 16 $\mathrm{ng} / \mathrm{ml}$ of oLeptin there was already a tendency $(P=$ $0.07)$ for reduced DNA synthesis. The highest dose of oLeptin $(160 \mathrm{ng} / \mathrm{ml})$ decreased IGF-I-stimulated DNA synthesis by $30 \%(P<0.001)$. Without the addition of

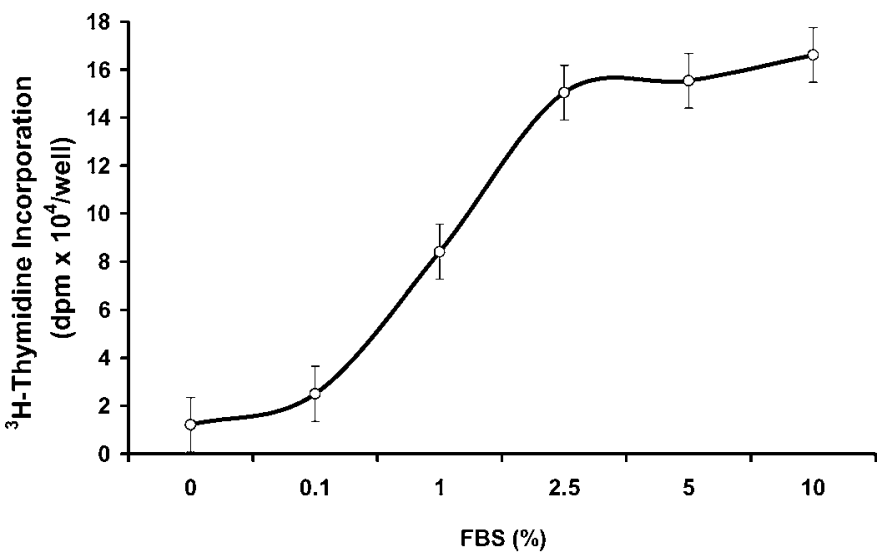

Figure 2. Effect of fetal bovine serum (FBS) on $\left[{ }^{3} \mathrm{H}\right]$-thymidine incorporation into a bovine mammary epithelial cell line (MAC-T). Cells were cultured in treatment medium for 3 days. A pulse of $\left[{ }^{3} \mathrm{H}\right]$-thymidine was given for the last $24 \mathrm{~h}$. Values are expressed as disintegrations/minute (dpm) and are presented as least square means SEM of two independent experiments ( $n=4$ blocks).

IGF-I, oLeptin at $100 \mathrm{ng} / \mathrm{ml}$ had no effect on the basal rate of DNA synthesis $(P=0.45$, not shown).

Addition of FBS greatly stimulated the rate of DNA synthesis (Figure 3). The dose of $1 \%$ FBS in the medium increased the rate of DNA synthesis by sevenfold (Figure 3), and was used to evaluate the effect of leptin on FBS-stimulated cell proliferation. The addition of 1 to $1,000 \mathrm{ng} / \mathrm{ml}$ of oLeptin to medium containing $1 \%$ FBS, decreased $(P<0.05)$ DNA synthesis by 14 to $29 \%$ (Figure 4).

\section{Leptin Receptor Expression by Bovine Tissues}

$\boldsymbol{O} \boldsymbol{b}-\boldsymbol{R} \boldsymbol{b}$. The mRNA for $\mathrm{Ob}-\mathrm{Rb}$ was detected in all tissues examined (Figure 5a). There was no difference in tissue distribution of $\mathrm{Ob}-\mathrm{Rb}$ mRNA between the different animals tested (not shown). The 402-bp cDNA was not detected following PCR using total RNA incubated without reverse transcriptase (negative control) as the template for each tissue (Figure 5b), demonstrating the absence of genomic DNA contamination. After digestion of the RT-PCR products with MseI endonuclease, the original RT-PCR product was no longer visible, and was replaced by a $\sim 200$-bp fragment in all tissues (Figure 5c). This smaller fragment likely represents both the 193- and 209-bp fragments that were expected (Figure 6) and demonstrated that the RT-PCR product amplified from all tissues contained the MseI restriction site at the expected location and thus encoded bovine Ob-Rb.

The Ob-Rb partial nucleotide sequence obtained (402-bp) displayed 99\% similarity with previously reported partial sequence of the bovine Ob-Rb (GenBank 


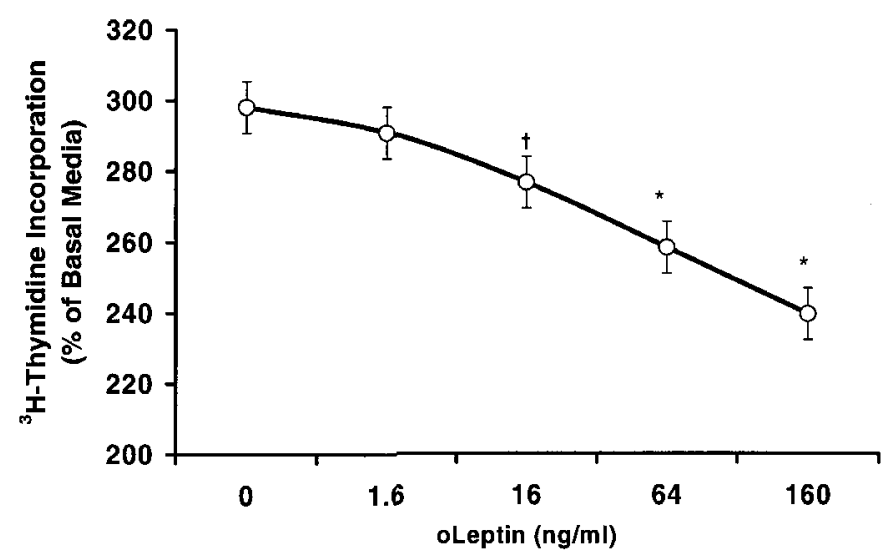

Figure 3. Effect of recombinant ovine leptin (oLeptin) on IGF-I (5 ng/ml)-stimulated bovine mammary epithelial cell line (MAC-T) DNA synthesis measured by $\left[{ }^{3} \mathrm{H}\right]$-thymidine incorporation. Cells were cultured in treatment medium for 3 days. A pulse of $\left[{ }^{3} \mathrm{H}\right]$-thymidine was given for the last $24 \mathrm{~h}$. Values are expressed as a percentage of basal media without IGF-I (disintegrations/minute of basal treatment $=4.2 \times 10^{4}$ ) and are presented as least square means SEM of four independent experiments ( $\mathrm{n}=7$ blocks). *Indicates that treatment is lower $(P<0.001)$ than dose 0 . $\dagger$ Indicates $\mathrm{P}=0.07$.

U62385), 93\% similarity with the ovine receptor (GenBank U62124), 85\% similarity with the swine receptor (GenBank AF092422), and 83\% similarity with the human receptor (GenBank U43168). The deduced bovine Ob-Rb partial AA sequence shared 100, 92, 78, 73 , and $68 \%$ similarity with sequences for the bovine, ovine, swine, human, and rat leptin receptors, respectively.

$\boldsymbol{O b}-\boldsymbol{R} \boldsymbol{a}$. In contrast to the widespread Ob-Rb expression observed in bovine tissues, Ob-Ra expression was detected in only three of the 14 tissues tested-liver, spleen, and pituitary (Figure 7a) — and was not detected in mammary parenchyma, isolated mammary epithelial cells, or MAC-T cells. There was no difference in tissue distribution of Ob-Ra among the different animals tested (not shown). Expression of RP-L19 was detected in all tissues (Figure 7b), thus demonstrating that the RT-PCR reactions were successful. The 275-bp cDNA was not detected following PCR using RT negative control as the template for each tissue (Figure 7c).

After digestion of the RT-PCR products with BseRI endonuclease, the original fragment was no longer visible, and was replaced by a 140 -bp fragment in all three tissues (Figure 7d). This smaller fragment likely represented both the 129- and 146-bp fragments that were expected (Figure 6), and demonstrated that the RT-PCR product in all tissues contained the BseRI endonuclease restriction site at the expected location.
The bovine Ob-Ra partial nucleotide sequence (275bp) shared $99 \%$ similarity with a previously published bovine adrenal Ob-Ra sequence (Yanagihara et al., 2000), 89\% similarity with the reported Ob-Ra human sequence (GenBank U50748), and 82\% similarity with the reported rat sequence (GenBank U84126). The deduced partial AA sequence obtained for the bovine ObRa shares 100,90 , and $80 \%$ similarity with sequences for the bovine, human, and rat Ob-Ra, respectively.

\section{DISCUSSION}

On average, high-energy diets promoting body growth rates above $1 \mathrm{~kg} / \mathrm{d}$ during the prepubertal phase impair mammary development 20\% (VandeHaar and Silva, 2002). At one time, the theory relating rapid growth of dairy heifers before puberty and decreased subsequent milk yield was that rapid body growth was associated with excess fat deposition in the udder (Swanson, 1960). Later, the predominant view was that fat itself was not the problem, but rather that high-energy intake caused hormonal changes, such as decreased serum concentrations of growth hormone, which reduces mammary development (Sejrsen et al., 1983). Recently, we found that even when heifers are fed the same diet, those that are the fattest around puberty have the least mammary parenchymal tissue (VandeHaar et al., 2001). McFadden and Cockrell (1993) observed decreased proliferation of bovine mammary epithelial cells when co-incubated with bo-

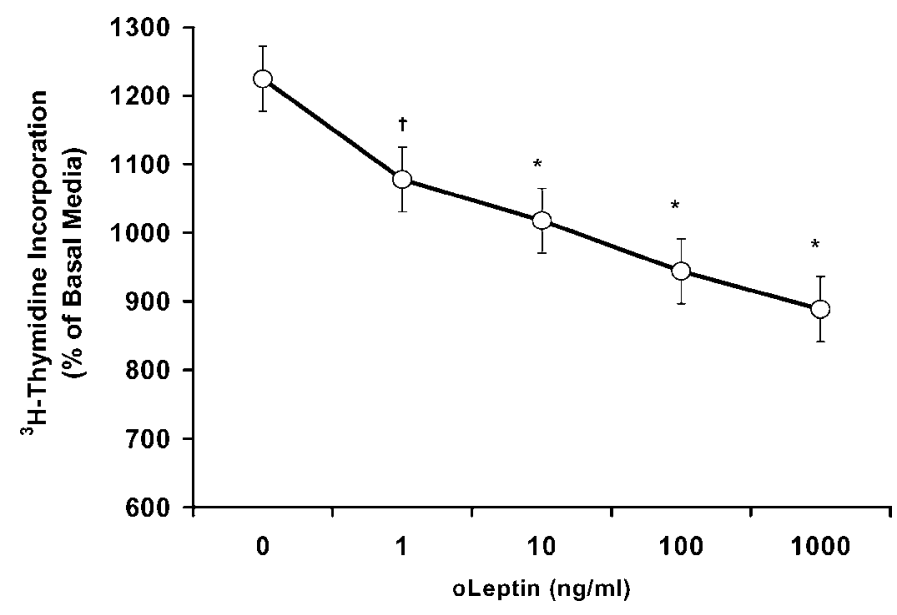

Figure 4. Effect of recombinant ovine leptin (oLeptin) on fetal bovine serum (1\%)-stimulated mammary epithelial cell-line cells DNA synthesis measured by $\left[{ }^{3} \mathrm{H}\right]$-thymidine incorporation. Cells were cultured in treatment medium for $3 \mathrm{~d}$. A pulse of $\left[{ }^{3} \mathrm{H}\right]$-thymidine was given for the last $24 \mathrm{~h}$. Values are expressed as a percentage of basal media without IGF-I (disintegrations/min of basal treatment $=7.4 \times$ $10^{3}$ ) and are presented as least squares means \pm SEM of four independent experiments $(\mathrm{n}=8$ blocks). *Indicates that treatment is lower $(P<0.001)$ than dose 0 . †Indicates $P=0.02$. 

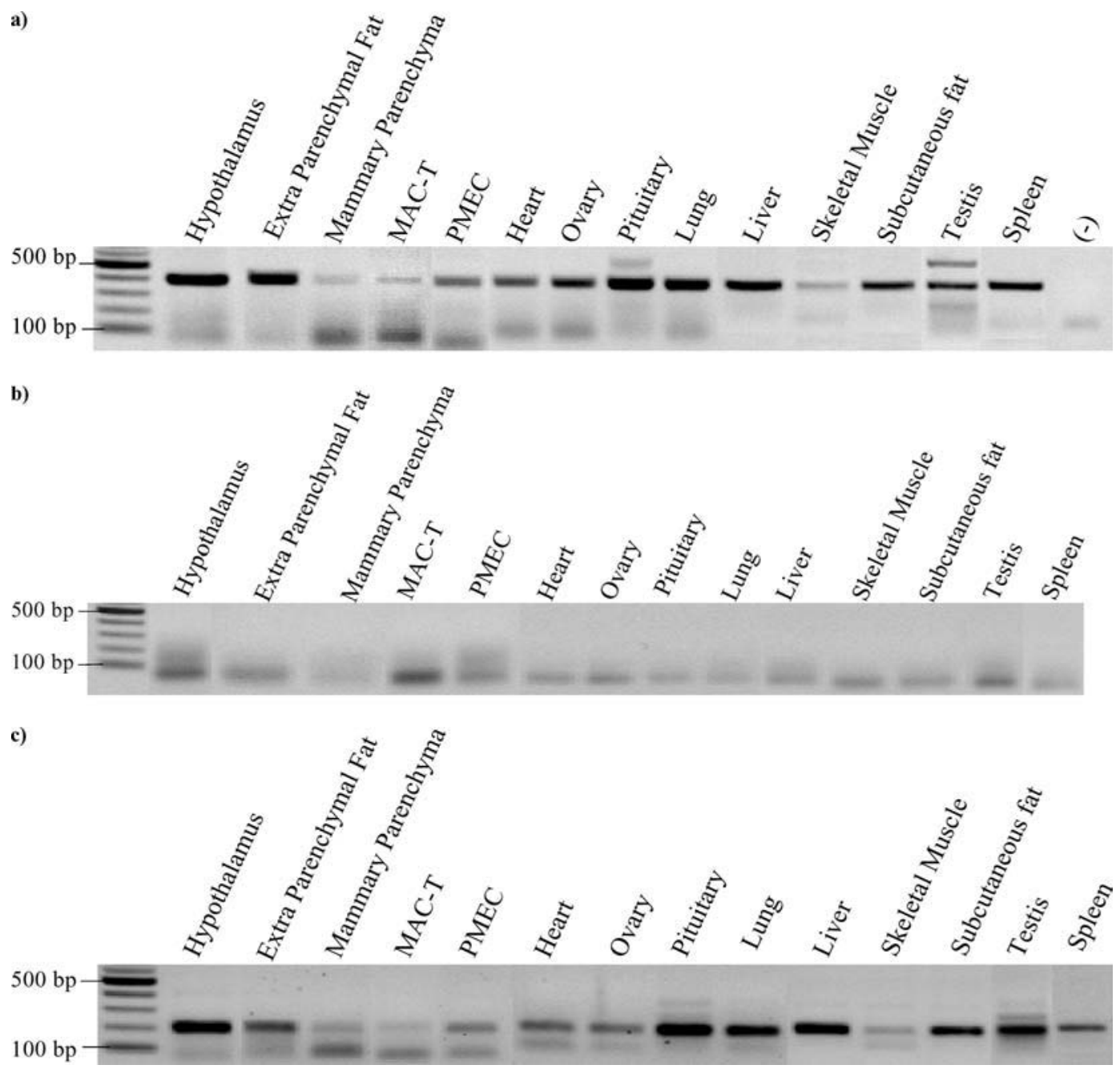

Figure 5. Tissue distribution of bovine leptin receptor (Ob-Rb) mRNA. Expression of bovine Ob-Rb mRNA was analyzed by reverse transcription PCR (RT-PCR) of RNA isolated from various tissues, mammary epithelial cell-line cells (MAC-T), and primary mammary epithelial cells (PMEC). a) Representative agarose gel demonstrating amplification of 402-base pair (bp) Ob-Rb cDNA from all tissues examined. (-) negative control (no RNA) reaction. b) Representative agarose gel demonstrating the absence of bands in the negative control reaction (no RTase). c) Representative agarose gel of RT-PCR products following MseI digestion. Note reduction in the size of PCR products to expected size following MseI digestion.

vine adipose tissue, supporting the idea that accumulation of fat is detrimental to optimal mammary development. These results suggested bovine adipose tissue secretes a compound that inhibits proliferation of mammary cells.

In the current study, we demonstrated that leptin, a hormone produced by adipocytes, antagonizes IGFI- and FBS-induced DNA synthesis of MAC-T. These results are in agreement with other models where leptin also inhibited proliferation of a mouse pituitary cell line and antagonized IGF-I-augmentation of steroidogenesis in ovarian cells (Jin et al., 2000; Agarwal et al., 1999).
Leptin concentration in the serum of cattle is normally between 5 to $10 \mathrm{ng} / \mathrm{ml}$ and increases with body fatness (Ehrhardt et al., 2000). Once bovine mammary parenchymal cells are able to synthesize leptin (Chilliard et al., 2001; Smith and Sheffield, 2002), it is possible that the local concentration of leptin in the mammary gland is higher than in serum. We analyzed leptin concentration in aqueous extracts prepared from mammary parenchymal tissue of three prepubertal heifers and found 10.4 to $12.1 \mathrm{ng}$ of leptin/g of tissue (unpublished data). In our model, doses of oLeptin to achieve similar to physiological concentrations were sufficient to decrease DNA synthesis, suggesting that 


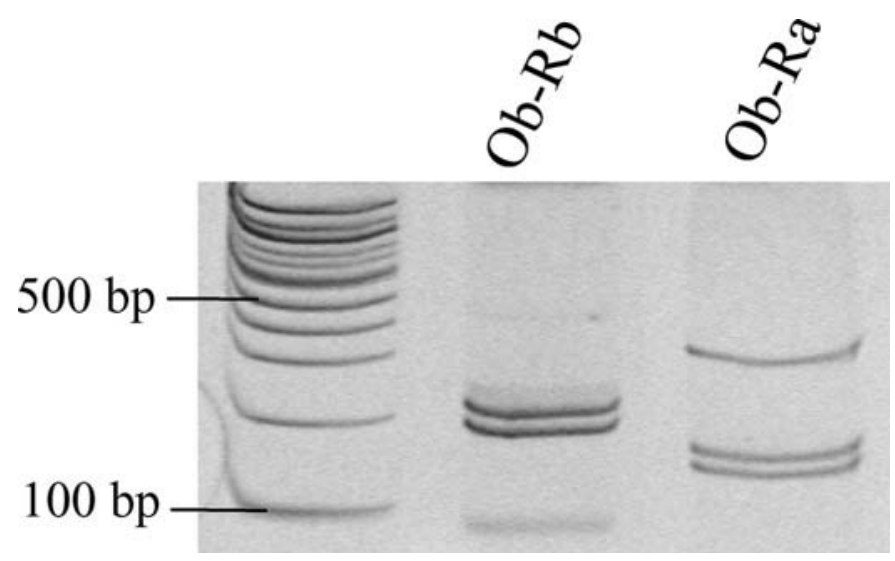

Figure 6. Representative polyacrylamide gel of bovine liver long form $(\mathrm{Ob}-\mathrm{Rb})$ or shortform (Ob-Ra) leptin receptor PCR products digested with MseI (Ob-Rb) or BseRI (Ob-Ra), confirming that the restriction enzyme digestion protocol yields two bands of predicted sizes for Ob-Rb and Ob-Ra products.

the increase in leptin concentration when heifers are fed high-energy diets could explain the impairment observed in mammary development.

Leptin inhibited DNA synthesis in FBS-stimulated cells in a fashion similar to IGF-I-stimulated cells, which suggests that leptin inhibition is not specific to IGF-I. If leptin inhibition of cell proliferation was specific to IGF-I, one would expect to see either a smaller or no effect of leptin on FBS-stimulated cells since there are several other growth factors present in FBS. Studies with growth factors other than IGFI are necessary to conclusively answer this question.

Our results point toward a direct action of leptin on the bovine mammary gland. If leptin is to have a direct effect on mammary parenchyma, the leptin receptor (Ob-R) must be expressed in the tissue. Five leptin receptor isoforms have been identified in the rodent: Ob-Ra, Rb, Rc, Rd, and Re (Tartaglia et al., 1995). Ob$\mathrm{Rb}$ has a long intracellular domain (302 AA), and is essential for the weight-reducing effect of leptin. The other isoforms lack some or all of Ob-Rb intracellular domains (Friedman and Halaas, 1998). Expression of leptin receptor mRNA in ovine mammary tissue has been reported; however, the specific Ob-R isoform expressed in ovine mammary epithelial cells was not identified (Laud et al., 1999).

Our results demonstrate that $\mathrm{Ob}-\mathrm{Rb} \mathrm{mRNA}$, and not Ob-Ra mRNA, is expressed in mammary epithelial cells in cattle. Expression of Ob-Rb mRNA in mammary epithelial cells suggests that leptin could act directly through receptor activation to inhibit proliferation and reinforces the evidence for a regulatory role of leptin in parenchymal growth. Similarly to primary mammary epithelial cells, MAC-T cells expressed Ob-
$\mathrm{Rb}$, but not Ob-Ra, supporting the use of MAC-T cells as a model for studying effects of leptin on bovine mammary gland.

$\mathrm{Ob}-\mathrm{Rb}$ is closely related to the interleukin-6 (IL-6) receptor and has very similar signaling capabilities (Baumann et al., 1996). IL-6 inhibits both human (Chiu et al., 1996) and bovine (Okada et al., 1999) mammary epithelial cell proliferation. In fact, IL-6 at $50 \mathrm{ng} / \mathrm{ml}$ decreases mammary cell proliferation $30 \%$ (Okada et al., 1999), which is similar to our data on leptin. It is possible that cytokines, leptin, and IL-6 act through similar post-receptor pathways to inhibit proliferation of mammary epithelial cells. One possible pathway for leptin-induced inhibition of mammary epithelial cell proliferation is activation of signal transducers and activators of transcription (STAT). Phosphorylated STATs can dimerize and migrate to the nucleus and function as transcription factors (Bjorbaek et al., 1999). Activation of STAT-3 can induce $\mathrm{G}_{0}$ growth arrest in mouse mammary epithelial cells (Hutt et al., 2000). Also, STAT-5 activation accelerates differentiation of mammary epithelial cells and decreases proliferation rate (Petersen and Haldosen, 1998). Leptin receptor signaling could also lead to increased secretion of IGF-binding proteins causing indirect inhibition of growth; however, these hypotheses remain to be tested.

Expression of $\mathrm{Ob}-\mathrm{Rb}$ was not unique to the bovine mammary gland. All 14 bovine tissues examined expressed Ob-Rb mRNA. This widespread expression of Ob-Rb mRNA observed in cattle is in agreement with Ob-Rb expression reported in pigs (Lin et al., 2000), and suggests that leptin may act directly in most bovine tissues. Whereas previous studies in rodents showed that $\mathrm{Ob}-\mathrm{Rb}$ is mainly expressed in the hypothalamus, it is also expressed at lower levels in several other tissues such as pituitary, liver, lung, kidney, uterus, testis, adipose tissue, heart, and spleen (Lollmann et al., 1997).

The tissue-specific expression of Ob-Ra mRNA (pituitary, liver, and spleen) observed in cattle was unexpected, based on the ubiquitous expression of Ob-Ra reported for mice (Lollmann et al., 1997). Activation of Ob-Ra can lead to Janus kinase and/or mitogenactivated kinase activation, but not STAT activation (Bjorbaek et al., 1997), and the function of Ob-Ra signaling is not known. Likewise, the physiological significance of tissue-specific expression of Ob-Ra in cattle is not known, but it is not related to mammary development as long as Ob-Ra is not expressed in bovine mammary gland.

In contrast to the negative effect of co-incubation of bovine mammary epithelial cells with bovine adipose tissue (McFadden and Cockrell, 1993), Hovey et al. 
a)

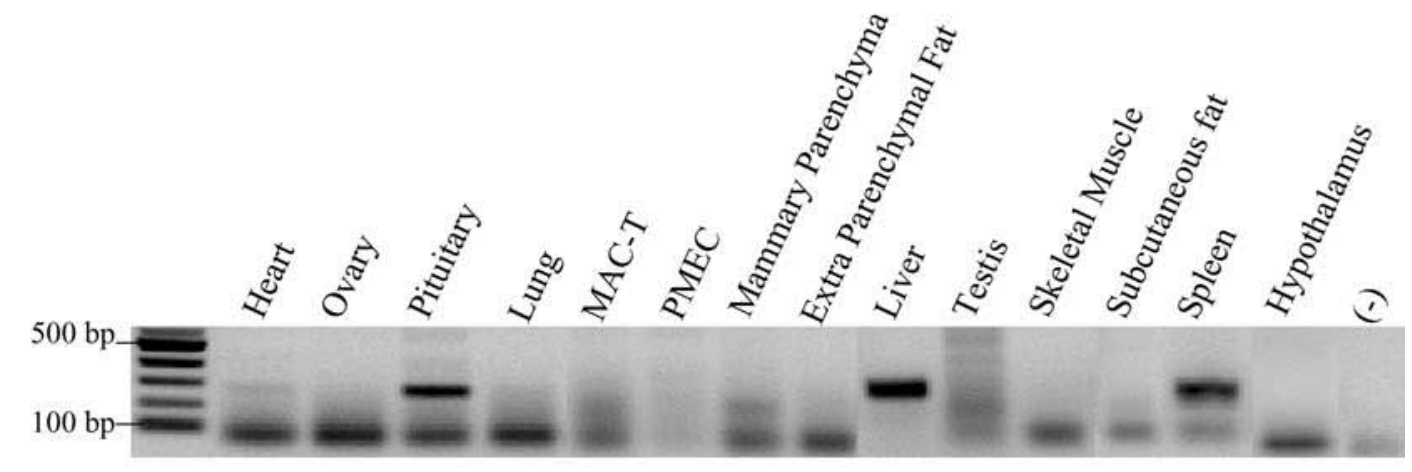

b)

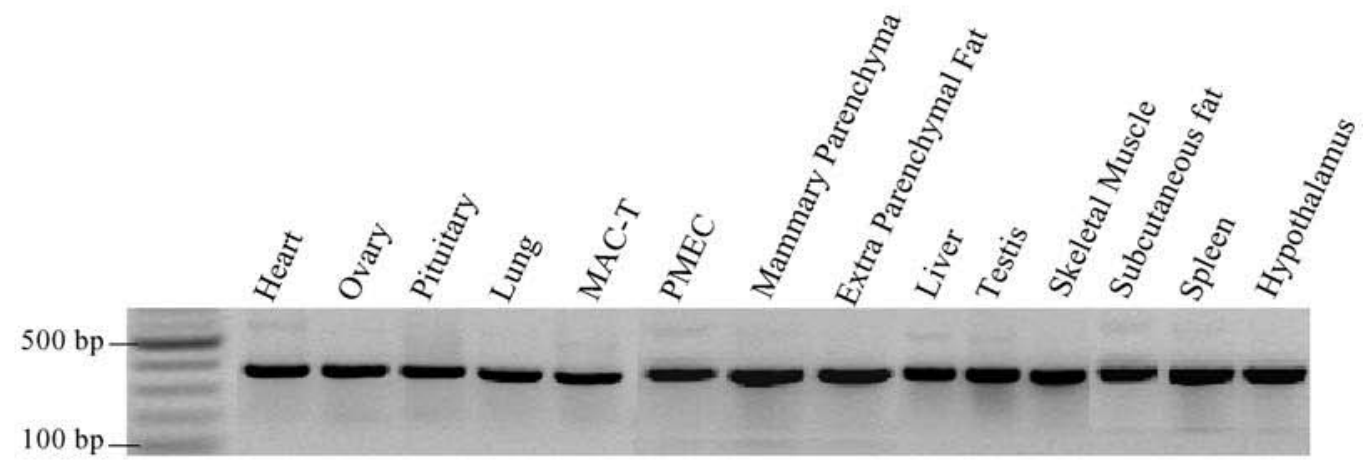

c)

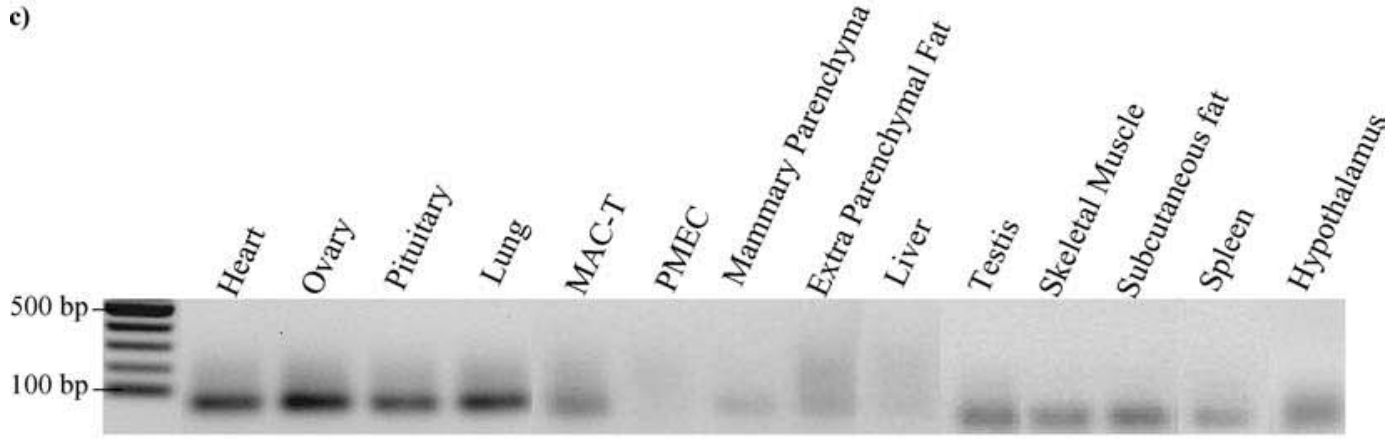

d)

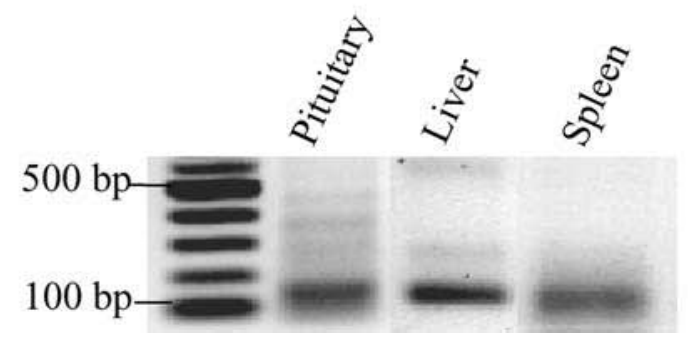

Figure 7. Tissue distribution of bovine leptin shortform receptor (Ob-Ra) mRNA. Expression of bovine Ob-Ra mRNA was analyzed by reverse transcription (RT) PCR of RNA isolated from various tissues, mammary epithelial cell-line cells (MAC-T), and primary mammary epithelial cells (PMEC). a) Representative agarose gel demonstrating amplification of 275-base pair (bp) Ob-Ra cDNA from bovine liver, spleen, and pituitary. (-) negative control (no RT) reaction. b) Representative agarose gel demonstrating amplification of 360-bp bovine ribosomal protein L-19 (RPL-19) cDNA (positive control) from the same RT reactions used for amplification of Ob-Ra and Ob-Rb. c) Representative agarose gel demonstrating the absence of bands in the negative control reaction (no RTase). d) Representative agarose gel of RT-PCR products following BseRI digestion. Note reduction in the size of the PCR products to expected size following BseRI digestion (also see Figure 6). 
(1998) reported a stimulatory effect of mouse fat pad when co-cultured with a mouse mammary epithelial cell line (COMMA-1D) mouse mammary epithelial cells. One possible explanation for the differential response of mouse and bovine epithelial cells to the coincubation with fat pad is the expression of $\mathrm{Ob}-\mathrm{Rb}$ in these cells. The present data suggest that tissue expression of $\mathrm{Ob}-\mathrm{R}$ is different for cattle and mice. Perhaps COMMA-1D cells do not express Ob-Rb, and therefore are not responsive to leptin secreted by the fat pad.

Expression of $\mathrm{Ob}-\mathrm{Rb}$ (the leptin receptor isoform with established signaling capacity) in the bovine mammary gland provides additional evidence for a direct action of leptin in the regulation of parenchymal growth.

\section{CONCLUSIONS}

Leptin, a hormone produced by adipocytes and elevated in serum of animals fed high-energy diets, decreases DNA synthesis of MAC-T cells. Also, MAC-T cells, bovine mammary parenchymal and extraparenchymal tissues, and other bovine tissues express mRNA-encoding Ob-Rb, the long isoform of the leptin receptor with complete intracellular domain. If leptin at physiological concentrations inhibits mammary development of heifers in vivo, it may help explain the inhibitory effect of high-energy diets on mammary development.

\section{ACKNOWLEDGMENT}

The authors would like to thank Dr. Arieh Gertler (Hebrew University of Jerusalem) for the provision of oLeptin; Nexia Biotechnologies (Quebec, Canada) for the MAC-T cells; and Dr. D. H. Keisler (University of Missouri) for the analysis of leptin concentration in mammary extracts.

\section{REFERENCES}

Agarwal, S. K., K. Vogel, S. R. Weitsman, and D. A. Magoffin. 1999. Leptin antagonizes the insulin-like growth factor-I augmentation of steroidogenesis in granulosa and theca cells of the human ovary. J. Clin. Endocrinol. Metab. 84:1072-1076.

Barb, C. R., X. Yan, M. J. Azain, R. R. Kraeling, G. B. Rampacek, and T. G. Ramsay. 1998. Recombinant porcine leptin reduces feed intake and stimulates growth hormone secretion in swine. Domest. Anim. Endocrinol. 15:77-86.

Baumann, H., K. K. Morella, D. W. White, M. Dembski, P. S. Bailon, H. Kim, C. F. Lai, and L. A. Tartaglia. 1996. The full-length leptin receptor has signaling capabilities of interleukin 6-type cytokine receptors. Proc. Natl. Acad. Sci. 93:8374-8378.

Bjorbaek, C., K. El-Haschimi, J. D. Frantz, and J. S. Flier. 1999. The role of SOCS-3 in leptin signaling and leptin resistance. J. Biol. Chem. 274:30059-30065.
Bjorbaek, C., S. Uotani, B. da Silva, and J. S. Flier. 1997. Divergent signaling capacities of the long and short isoforms of the leptin receptor. J. Biol. Chem. 272:32686-32695.

Capuco, A. V., J. J. Smith, D. R. Waldo, and C. E. Rexroad Jr. 1995. Influence of prepubertal dietary regimen on mammary growth of Holstein heifers. J. Dairy Sci. 78:2709-2725.

Chen, N. G., A. G. Swick, and D. R. Romsos. 1997. Leptin constrains acetylcholine-induced insulin secretion from pancreatic islets of ob/ob mice. J. Clin. Invest. 100:1174-1179.

Chilliard, Y., M. Bonnet, C. Delavaud, Y. Faulconnier, C. Leroux, J. Djiane, and F. Bocquier. 2001. Leptin in ruminants. Gene expression in adipose tissue and mammary gland, and regulation of plasma concentration. Domest. Anim. Endocrinol. 21:271-295.

Chiu, J. J., M. K. Sgagias, and K. H. Cowan. 1996. Interleukin 6 acts as a paracrine growth factor in human mammary carcinoma cell lines. Clin. Cancer Res. 2:215-221.

Delavaud, C., F. Bocquier, Y. Chilliard, D. H. Keisler, A. Gertler, and G. Kann. 2000. Plasma leptin determination in ruminants: effect of nutritional status and body fatness on plasma leptin concentration assessed by a specific RIA in sheep. J. Endocrinol. 165:519-526.

Eckles, C. H. 1915. The ration and age of calving as factors influencing the growth and dairy qualities of cows. Res. Bull. No. 135. M.O. Agric. Exp. Stn., Columbia, MO.

Ehrhardt, R. A., R. M. Slepetis, J. Siegal Willott, M. E. Van Amburgh, A. W. Bell, and Y. R. Boisclair. 2000. Development of a specific radioimmunoassay to measure physiological changes of circulating leptin in cattle and sheep. J. Endocrinol. 166:519528.

Friedman, J. M., and J. L. Halaas. 1998. Leptin and the regulation of body weight in mammals. Nature 395:763-770.

Ghilardi, N., S. Ziegler, A. Wiestner, R. Stoffel, M. H. Heim, and R. C. Skoda. 1996. Defective STAT signaling by the leptin receptor in diabetic mice. Proc. Natl. Acad. Sci. 93:6231-6235.

Houseknecht, K. L., C. A. Baile, R. L. Matteri, and M. E. Spurlock. 1998. The biology of leptin: a review. J. Anim. Sci 76:1405-1420.

Hovey, R. C., S. MacKenzie, and T. B. McFadden. 1998. The proliferation of mouse mammary epithelial cells in response to specific mitogens is modulated by the mammary fat pad in vitro. In Vitro Cell. Dev. Biol. Anim. 34:385-392.

Hutt, J. A., J. P. O’Rourke, and J. DeWille. 2000. Signal transducer and activator of transcription 3 activates CCAAT enhancerbinding protein delta gene transcription in G0 growth-arrested mouse mammary epithelial cells and in involuting mouse mammary gland. J. Biol. Chem. 275:29123-29131.

Huynh, H. T., G. Robitaille, and J. D. Turner. 1991. Establishment of bovine mammary epithelial cells (MAC-T): an in vitro model for bovine lactation. Exp. Cell Res. 197:191-199.

Jin, L., S. Zhang, B. G. Burguera, M. E. Couce, R. Y. Osamura, E. Kulig, and R. V. Lloyd. 2000. Leptin and leptin receptor expression in rat and mouse pituitary cells. Endocrinology 141:333-339.

Laud, K., I. Gourdou, L. Belair, D. H. Keisler, and J. Djiane. 1999. Detection and regulation of leptin receptor mRNA in ovine mammary epithelial cells during pregnancy and lactation. FEBS Lett. 463:194-198.

Lin, J., C. R. Barb, R. L. Matteri, R. R. Kraeling, X. Chen, R. J. Meinersmann, and G. B. Rampacek. 2000. Long form leptin receptor mRNA expression in the brain, pituitary, and other tissues in the pig. Domest. Anim. Endocrinol. 19:53-61.

Lollmann, B., S. Gruninger, A. Stricker Krongrad, and M. Chiesi. 1997. Detection and quantification of the leptin receptor splice variants $\mathrm{Ob}-\mathrm{Ra}, \mathrm{b}$, and, e in different mouse tissues. Biochem. Biophys. Res. Commun. 238:648-652.

McFadden, T. B., and D. C. Cockrell. 1993. Regulation of growth in cultured mammary epithelium from beef and dairy heifers. Proc. N.Z. Soc. of Anim. Prod. 53:143-145.

Okada, H., Y. Miyake, H. Ohtsuka, Y. Kiku, S. Fukuda, A. Watanabe, Y. Yokomizo, T. J. Rosol, and T. Yoshino. 1999. Effects of isoprothiolane on cell growth of cultured bovine mammary epithelial cells. J. Vet. Med. Sci. 61:553-556. 
Petersen, H. and L. A. Haldosen. 1998. EGF modulates expression of STAT5 in mammary epithelial cells. Exp. Cell Res. 243:347-358.

Radcliff, R. P., M. J. VandeHaar, L. T. Chapin, T. E. Pilbeam, D. K. Beede, E. P. Stanisiewski, and H. A. Tucker. 2000. Effects of diet and injection of bovine somatotropin on prepubertal growth and first-lactation milk yields of Holstein cows. J. Dairy Sci. 83:23-29.

Radcliff, R. P., M. J. VandeHaar, A. L. Skidmore, L. T. Chapin, B. R. Radke, J. W. Lloyd, E. P. Stanisiewski, and H. A. Tucker. 1997. Effects of diet and bovine somatotropin on heifer growth and mammary development. J. Dairy Sci. 80:1996-2003.

SAS User's Guide: Statistics, Version 8 Edition. 2000. SAS Inst., Inc., Cary, NC.

Sejrsen, K., J. T. Huber, and H. A. Tucker. 1983. Influence of amount fed on hormone concentrations and their relationship to mammary growth in heifers Cattle. J. Dairy Sci. 66:845-855.

Sejrsen, K., J. T. Huber, H. A. Tucker, and R. M. Akers. 1982. Influence of nutrition on mammary development in pre- and postpubertal heifers. J. Dairy Sci. 65:793-800.

Smith, J. L., and L. G. Sheffield. 2002. Production and regulation of leptin in bovine mammary epithelial cells. Domest. Anim. Endocrin. 22:145-154.

Swanson, E. W. 1960. Effect of rapid growth with fattening of dairy heifers on their lactational ability. J. Dairy Sci. 43:377-387.

Tartaglia, L. A., M. Dembski, X. Weng, N. Deng, J. Culpepper, R. Devos, G. J. Richards, L. A. Campfield, F. T. Clark, J. Deeds, et al. 1995. Identification and expression cloning of a leptin receptor, OB-R. Cell. 83:1263-1271.

VandeHaar, M. J., and L. F. P. Silva. 2002. Feeding Dairy Heifers for Optimal Growth and Mammary Development. Proc. 6th Prof. Dairy Heifers Growers Assoc. Ann. Conf., Baltimore, MD.

VandeHaar, M. J., L. F. P. Silva, B. K. Whitlock, R. P. Radcliff, and H. A. Tucker. 2001. Relationship of body growth to mammary development in dairy heifers. Proc. 5th EAAP/ASAS/ADSA Joint Workshop Biol. of Lactation Farm Anim. The Hague, The Netherlands. Livest. Prod. Sci. 70(Special Issue):176.

Weber, M. S., S. Purup, M. Vestergaard, S. E. Ellis, J. ScndergardAndersen, R. M. Akers, and K. Sejrsen. 1999. Contribution of insulin-like growth factor (IGF)-I and IGF-binding protein-3 to mitogenic activity in bovine mammary extracts and serum. J. Endocrinol. 161:365-373.

Woodward, T. L., R. M. Akers, and J. D. Turner. 1994. Lack of mitogenic response to EGF, pituitary and ovarian hormones in bovine mammary epithelial cells. Endocrine 2:529-535.

Yanagihara, N., K. Utsunomiya, T. B. Cheah, H. Hirano, K. Kajiwara, K. Hara, E. Nakamura, Y. Toyohira, Y. Uezono, S. Ueno, and F. Izumi. 2000. Characterization and functional role of leptin receptor in bovine adrenal medullary cells. Biochem. Pharmacol. 59:1141-1145.

Zhang, Y., R. Proenca, M. Maffei, M. Barone, L. Leopold, and J. M. Friedman. 1994. Positional cloning of the mouse obese gene and its human homologue. Nature 372:425-432. 